\title{
Virtual farmers markets: A reflective essay on a rural Ohio project
}

\author{
Brian Raison ${ }^{\text {a }} *$ \\ Ohio State University \\ John C. Jones b \\ Virginia Commonwealth University
}

Submitted February 23, 2020 / Revised April 13 and May 8, 2020 / Accepted May 8, 2020 /

Published online August 7, 2020

Citation: Raison, B., \& Jones, J. (2020). Virtual farmers markets: A reflective essay on a rural

Ohio project. Journal of Agriculture, Food Systems, and Community Development, 9(4), 299-310.

https://doi.org/10.5304/jafscd.2020.094.020

Copyright (C) 2020 by the Authors. Published by the Lyson Center for Civic Agriculture and Food Systems. Open access under CC-BY license.

\begin{abstract}
This reflective essay discusses the development, structure, operation, and transitioning of an online virtual farmers market in rural Ohio. In this model, customers order online and then pick up their fresh, local produce at a specified time and location. Through a combination of practitioner experience in the market's development and informal discussions with people associated with the market's development and management, the authors analyze the positive and negative aspects of the online market structure and implementation, as well as suggest critical steps that may be necessary
\end{abstract}

a * Corresponding author: Brian Raison, Department of Extension, Ohio State University; 3 Ag. Admin Building, 2120 Fyffe Road; Columbus, Ohio 43210 USA; +1-614-292-6181; raison.1@,osu.edu

b John C. Jones, Assistant Professor, Institute for Inclusion, Inquiry, and Innovation (iCubed), Center for Environmental Studies; Virginia Commonwealth University; 1000 West Cary Street; Richmond, Virginia 23284 USA; jonesj39@,vcu.edu to export this model to other communities. They also consider potential structural and process improvements that could increase viability and success. A last-minute addendum briefly discusses the potential for this model to become a meaningful response to the COVID-19 issue as well.

\section{Disclosure}

The first author of this reflective essay was directly involved in the conception, planning, fundraising, and implementation of this project, as part of his role as an Extension educator serving the area in which it was conducted. We hope this association will provide helpful insight as others study or consider conducting similar projects. Note: We have used the USDA's spelling of "farmers market," which does not include possessive case punctuation.

\section{Funding Disclosure}

The project discussed in this case study was funded by U.S. Department of Agriculture National Institute of Food and Agriculture (USDA NIFA) Farmers Market Promotion Program (FMPP) Grant \#15FMPPOH0008. The investigation, reflection, and written review presented herein were not included and had no external funding. 


\section{Keywords}

Farmers Market, Virtual Farmers Market, Food Council, Local Food, Online Farmers Market, COVID-19

\section{COVID-19 Addendum}

This manuscript went to peer review at the same time the COVID-19 pandemic emerged. We have given much contemplation to the now prescribed "social distancing" (physical distancing) as we have moved our academic classes and Extension programming online. In addition, we have paid close attention to conversations among food systems researchers, educators, and practitioners who, in real time, have been tackling the crisis in earnest. They have asked if and how farmers markets can survive. In April and May, many states had mandatory "stay at home" orders; unessential gathering places were mandated closed just when traditional in-person farmers markets should have been opening for the season. Many states began re-opening in June and July. But COVID cases spiked in some areas, and more restrictions were enforced.

The structure of this online virtual farmers market inherently provides physical distancing and consumer safety, which have been necessitated during this pandemic. The farmer/producer controls food safety within their field, packing, and transportation circles. The customer singularly selects and orders their food online. Limited interaction does occur with farmer drop-off at the aggregation point and with customer pick up, but as with grocery store precautions, those exposures can be mitigated.

In brief, we believe a digital platform such as the one outlined in this reflective essay may help to mitigate pandemic effects on proximate food systems. We are watching and hope to see increased use of these virtual interfaces not only for benefits outlined herein but as a meaningful response to the COVID-19 issue as well.

\section{Introduction}

Though U.S. farmers markets have long held the aesthetic of an in-person, communal, and even friendship opportunity among growers and consumers, there has been a considerable decline in the number of farms that sell directly to consumers and wholesalers in recent years (O'Hara \& Benson, 2019). The interest and growth in online shopping have made some speculate that farmers markets have peaked and may, in fact, now face a decline (Low et al., 2015). However, farmers, along with other geographically based local-scale food entrepreneurs seeking to tap into the growing demand for online retail, may face difficult issues of scale and delivery costs. For example, through Facebook or other social media platforms, a customer could place an order with a local farmer in largely the same way they might order a bathmat through Amazon. However, the delivery of (for example) US $\$ 10$ worth of leafy greens to that same doorstep could potentially cost a local farmer a similar amount in labor and travel costs, effectively making such a distribution system untenable. The farmer's problem lies not with connecting with customers through the Internet, but with the economies of scale required to deliver produce to customers' doorsteps (Lutz, Smetschka, \& Grima, 2017). In food-related sales, Kroger, Walmart, and other traditional grocery stores offer "click-lists" in which customers shop online, then drive through to pick up their food or goods at a scheduled time. News reports indicate that these have increased dramatically since the third week of March 2020, with the onset of the COVID-19 pandemic. The convenience factor of this system seems to make even the nominal fee, charged by some, of little consequence (Anesbury, Nenycz-Thiel, Dawes, \& Kennedy, 2016).

Convenience has shown up as a major factor that consumers cite for their online food purchasing. Morganosky and Cude (2000), who studied reasons for buying food online over 20 years ago, found convenience and time savings as the main motivators. They also found that mothers with small children and people with disabilities highly valued online grocery shopping. Long et al. (2013) found that convenience was a key to a consumer's decisions for making local food purchases (e.g., due to the limited hours of farmers markets). Yeo, Goh, and Rezaei (2017) also noted that specific convenience factors (reducing time and energy consumers expend) were important for consumers who used online food delivery services. Along with practical goals such as quality, taste, and nutrition, a 
study by Brekken, Parks, and Lundgren (2017) noted that convenience was considered "important" or "somewhat important" by $79.5 \%$ of respondents to the question of interests in obtaining local fresh produce.

Debra Tropp (2019) recently reflected that the growing popularity of hybrid business models "that transcend traditional local food system silos" (p. 28) makes it imperative that we understand coming shifts and synergies in market practice, for example, with Millennials and Generation Z members. The hybrid models, in this case, refer to direct-to-consumer and intermediated sales of locally grown and produced foods. Tropp (2019) notes that they "will exert even greater influence on local food demand" (p. 28) and lists convenience as a key component of how they may develop their local food purchasing habits and store format choices.

So is convenience enough of a factor to make a new online virtual farmers market successful and sustainable? If so, what characteristics (e.g., structural, financial, marketing, infrastructure) would be necessary for a group of farmers and other local food entrepreneurs to leverage the power of the Internet to create the economies of scale necessary to make digitalization profitable. In other words, would an online order and local pick-up system work for farmers market shoppers? Would convenience outweigh the in-person experience? Or, could there be an entirely new classification of a local food shopper perhaps not yet identified by the mainstream purveyors at farmers markets? That is, one who wants to know where their food is grown, who wants to support the local economy, but who does not have time to go to an in-person farmers market?

This article reflects on the development and the initial management of the Miami County Virtual Farmers Market, a digital interface through which several dozen local food growers and producers market their goods, harvest only what has been purchased, and deliver it to a central location for weekly pick-up by the online customers. The market is operated located in a largely rural county in western Ohio. Although the market was still in operation as of May 2020, this article provides a snapshot in time of the market's development and operation from 2015 to 2018. One of this article's authors was personally involved in the market's development during this period. While the market did not accomplish all the goals initially envisioned by its founders, reflections on its development process may inform other groups seeking to establish similar online markets, especially in less dense or rural regions.

\section{Online Virtual Farmers Markets: History and Background}

The concept of an online virtual farmers market for locally produced foods appears to be a very recent innovation. Based on our Internet research, we have seen it emerging only in the last 10 to 15 years, and mostly in more urban locations with larger populations. At its core, an online virtual farmers market allows multiple farmers to sell produce to multiple customers using the Internet while using a centralized distribution point(s) in the physical world to arrange for both drop-off and pick-up of that produce. Multiple farmers, all delivering to the same centralized location, create a critical mass that allows, through fees to the market, the maintenance of refrigeration and other storage devices at the distribution site.

Despite the concept's recent evolution, numerous examples of online markets at which consumers can shop at their convenience and later pick up or have their foods delivered to their doorstep already exist. In Brooklyn, New York, San Francisco, California, New Orleans, Louisiana, and Los Angeles, California, the Good Eggs virtual market has been satisfying customers for several years and continues to grow (Wortham, 2013). Wortham (2013) notes that New York also has Urban Organic and Next Door Organics, along with companies like Quinciple that specialize in artisanal food delivery. It appears that most of the distribution points for these examples exist in established urban areas, suggesting that densely populated areas offer the necessary critical mass for a viable market. That said, Local Food Marketplace (established in Eugene, Oregon, in 2009) offers online connections for farms, food hubs, and marketplace selling; however, according to examples on their website, their platforms appear workable in both urban and rural areas. 
White (2011) notes that there are conveniences for both consumers and farmers when buying and selling through an online virtual farmers market. Customers do not have to arrive at the farmers market first thing in the morning to get the best produce. Additionally, customers do not have to accept random items as they would in a community supported agriculture (CSA) share. For farmers, instead of guessing the amount of produce they might sell at the in-person market, they are able to harvest only what has been ordered, eliminating any wasted product. Farmers also get the convenience of knowing exactly what produce they must harvest and what amounts. They also have the additional benefit of selling remaining produce at a traditional farmers market or another venue. But for any of this to transpire, software that allows for the digital connection between producers and customers is required.

Perhaps the earliest example of such software and its associated market dates back roughly to roughly 2002, when Eric Wagoner of Athens, Georgia, launched http://locallygrown.net/. A University of Tennessee Extension study profiled the primary features of Locallygrown.net, and provided limited case studies of its use (Grigsby \& Bruch Leffew, 2016). According to the profile, service charges for markets are 3\% if all customers pay in cash and roughly 7\% (a combination of software costs, security fees, and transaction fees) if customers are allowed to pay online, and there are no upfront costs for markets who join. According to a 2011 Mother Earth News article, Wagner said his Athens market had combined weekly sales of US $\$ 8,000$ to US $\$ 12,000$, depending on the season (White, 2011). It also described how he copied the platform to create a template that any entrepreneurial farmer or farm market manager could use. According to Wagoner's website, 300 online markets are currently operating nationally, and 140 are in development (Locally Grown, 2018).

Over time, other online platforms have emerged. In 2009, Farmigo built a software system that would allow any local farm to offer online ordering. They have grown to service over 300 farms in more than 20 states (Wortham, 2013). In Africa, the Virtual Farmers' Market (VFM) app helps farmers advertise and sell surplus crops
(World Food Programme, 2018). The VFM app launched in May 2017. Developers targeted 2,500 Zambian farmers intending to connect them with 70 national and international buyers and become sustainable after three to five years. The app allows farmers to negotiate fair prices and make deals transparently. Additionally, the farmers also gain bargaining power and a potential for higher profits through the real-time pricing information provided by the app.

One possible critique of the idea of online virtual farmers markets is the potential for the socalled "digital divide" between more affluent and less affluent customers. The former possess smart phones and are accustomed to purchasing goods online, but the less affluent customers are often less financially and culturally able to purchase goods online. Given the recent evolution of farmers markets, research on this conflict is limited. Freedman et al. (2016) indicated that traditionally, markets can create targeted marketing, especially in targeted languages, and provide tours to local residents to increase customer diversity. The mostly digital nature of a market using this model may restrict the ability of well-intentioned market managers to reach out to these potential customers. However, Skizim et al.'s (2017) analysis of social marketing for farmers markets in a low-income region of Louisiana suggests that Internet and social media access is not a significant barrier for low-income individuals to access information about farmers markets.

\section{The Case of Rural Western Ohio}

The examples of online virtual farmers markets that we discovered seem to exist mostly in densely populated, urban areas. However, Miami County, Ohio, is a predominately rural county in western Ohio. As of the 2010 Census, 102,503 people lived in county, with a population density of 252 people per square mile (U.S. Census Bureau, 2010). The city of Troy is the county seat, which as of the 2010 Census had a population of 25,179 (U.S. Census Bureau, 2010). Commodity monoculture (e.g., feed corn and soybean) dominates the agricultural production of the county. The county's three largest cities are all located along the Interstate 75 corridor that links the Dayton and Cincinnati metro- 
politan regions to the south with northern Ohio and Michigan. The manufacture of automobile parts once played a major role in the economies of each of these urban areas. However, post-industrial forces have reduced (but not completely eliminated) this sector of the local economy. In the last two decades, sprawl from the Dayton metropolitan region has expanded into southern Miami County.

Although some coordination efforts around local food system projects do exist, Jones (2018) indicated that a lack of regional aggregation prevents many urban farmers in the nearby greater Dayton region from expanding their growing operations. We did find, however, that at least two CSA farmers in the area changed to home delivery models in the middle 2010s (Jones, 2018). Cuy Castellanos, Jones, Christaldi, and Liutkus (2017) noted a disconnect between local government officials and agents of civil society interested in local food system development and noted that local entrepreneurs might limit cooperation at a regional scale. Within this context, a citizen-grower group was formed in Miami County with guidance from the local Ohio State University (OSU) Extension office (led by this article's lead author) to investigate the possibility of creating more support for selling locally grown and produced foods.

\section{Development and History of the Miami County Virtual Farmers Market}

In the summer of 2013, we invited a diverse group of 22 people-representing local farmers, growers, businesses, farm-related organizations, public health, government, and citizens - to meet at the local OSU Extension office in Troy, Ohio. We discussed how we might place local food and agricultural economic development on the agendas of public policy-makers, private business leaders, not-for-profit institutions, and citizens. From that initial 2013 meeting, the Miami County Local Food Council was formed. We discussed projects that could help Miami County growers expand their markets and connect with new or potential consumers beyond the existing local traditional farmers markets. We outlined the ultimate goal as expanding opportunities for working together, creating jobs, doing business, and expanding the agricultural and local foods economy in their area (Raison,
2013). We then created a mission statement to guide actions: "To develop, support, and promote local food farmers and producers" (Raison, 2015). As we continued meeting, we again partnered with OSU Extension and undertook a modified strategic planning process that resulted in the formation of additional working groups (both short-term and ongoing teams) that would tackle specific tasks and activities. One of these teams began exploring the possibilities of starting an online virtual farmers market.

In November of 2015, with OSU Extension as the lead partner, we received a US $\$ 45,000$ USDA Local Food Promotion Program (LFPP) grant to fund the salary of a market manager and launch a new online market in early 2016. The mission was to connect local consumers with local foods through simple technology. The vision: "The Miami County Virtual Farmers Market provides an easy way for consumers and producers to buy and sell local goods, supporting the local economy and encouraging healthy eating while building positive community relationships." After a few weeks of research into various online selling platforms, we chose Wagner's locallygrown.net online venue due to its low cost and ease of website setup and navigation. The council hired a market manager at 20 hours per week and began setting up the market.

\section{Market Prep and Manager Work}

In the late summer of 2016, as we entered the preparation period just prior to the market opening, our newly hired manager, with board assistance, constructed an outline of activities that would be necessary to undertake:

- Generate farm/grower list. Invite and hold vendor information meetings.

- Write press releases and distribute them to local news media outlets, including online social media channels.

- Interview early vendor businesses/farms. Compile vendor features to spotlight a new vendor each week on the market site and blog, including pictures.

- Read and become familiar with cottage food and retail food restrictions, labeling requirements, and plan review requirements. 
- Meet with county health officials and managers of the market pickup location to finish plans, review application, and ready the space for market use.

- Create a Facebook account with updates, links to the website, new products, vendor features, product pictures, etc.

- E-mail potential customers, detailing the structure of the market, the advantages of participating, and how to join our community.

- Verify the county health department and Ohio Department of Agriculture requirements to ensure all vendors are properly licensed and prepared for a retail market.

- Design, print, and distribute publicity posters and postcards among area businesses and potential customers.

- Research commercial refrigerators and freezers (health department-compliant models) that will work with our retail food license.

- Learn the licensed website's computer coding necessary to change anything needed in the default settings.

- Research other Locally Grown sites to see what products they offer, how they structure their market and website, what their requirements and restrictions are, etc. Send vendors helpful hints and suggestions to assist their entrance in the market and their continued participation.

- Create action lists and team-building exercises for the food council volunteers and board members who will rotate helping out at drop-off, to help transform them from occasional participants to vested members of the community we are creating.

Here is an overview of how the online market ordering process works:

\section{- Market Process Flow:}

Each week, our farmers, artisans, and producers list all the products they currently have to offer on the website under their farm's name and branding. They have individual log-in pages that allow them to specify exactly how much of any given item might be available each week (e.g., "We'll have only 10 dozen eggs this week."). They may also add photos.

- Product Line Variety:

Products vary weekly, depending on the time of year. But from the beginning, we worked to offer a wide variety of products, including vegetables, fruits, meats, eggs, baked goods, desserts, dairy products, fresh flowers, live plants, jams, jellies, fruit butters, dried herbs and mixes, teas, sugar alternatives such as maple syrup, honey and sorghum, soaps, body care products, and artisan crafts for the kitchen and home.

\section{- Customer Ordering:}

Every Tuesday at 9 pm, a list of available products is e-mailed to everyone with a free Miami County Locally Grown Virtual Market account. Customers may place their order for the week any time between Tuesday at $9 \mathrm{pm}$ and Sunday at $8 \mathrm{pm}$. Orders are only placed via this website, and payment are not made until pickup.

\section{- Vendor Harvest Order:}

Vendors receive a customized list of what has been ordered by e-mail each Sunday night after the market closes for the week. They then harvest only what customers have ordered (on Monday or Tuesday) and deliver it to the market before $4 \mathrm{pm}$ on Tuesday.

\section{- Customer Pickup:}

Customers receive an e-mail reminder to pick up their order from $5 \mathrm{pm}$ to $7 \mathrm{pm}$ on Tuesday.

\section{Sales and Details}

Our Miami County Locally Grown Virtual Farmers Market opened August 2, 2016, with 160 registered customers who were recruited while we were setting up the online operation. We had also simultaneously recruited 13 farmers and producers to participate during this period (and began training 
them on posting products, interfacing with the back end of the website, and even helping with some marketing ideas). By year-end, we had just under 400 customers and 20 vendors.

The first 10 weeks of operations saw 148 total orders, for an average of 15 orders per week. The lowest week had only 11 orders; the highest had 22. The total sales over the first 10 week were US $\$ 5,033$ or about US $\$ 500$ per week. Although the grant covered our market manager's salary, we began calculating what sales volume might be required (via a 10\% market hold-back fee from the vendors/farmers) to sustain the position for the long term. Through Thanksgiving of our first year (19 total weeks of sales), we had 301 total orders or an average of 17.7 per week. Sales totaled US $\$ 11,820$ for an average of US $\$ 622$ per week.

During the winter months of early 2017, sales slowed somewhat. But during the first 10 weeks of spring (weeks 34-43, or April 4-July 3), we had 308 orders, or nearly 31 orders per week on average. These 10 weeks saw total sales of US $\$ 10,341$ or just over US $\$ 1,000$ per week. This increase in sales made sense to us, as customers enthusiastically talked about their excitement of having fresh produce again after the winter months.
In summary, the 64 weeks of sales covered in the scope of this review grossed just over US $\$ 48,240$, with 35 participating farmer/producers and over 560 registered customers. The weekly sales graph (Figure 1) provides a weekly sales trend line for the 64 weeks covered in this project's timeframe. Please see the Appendix for a table of weekly sales.

\section{Market Transition Away from Food Council Control}

At the conclusion of the LFPP grant, we investigated ways to restructure the financials so that market fees could fully cover the manager's parttime salary (which had been funded at 20 hours per week for two years under the grant). But that formula would have required gross sales to nearly double to achieve the desired salary recovery from market fees. So the food council's involvement with the market ended formally on January 30, 2018. However, the manager was willing to attempt to keep the market going by incorporating it as a for-profit business, and, with few assets and the grant ended, the council agreed to give up the Miami County Locally Grown name, website domain, and customer list of the market in the

Figure 1. Weekly Sales (US\$)

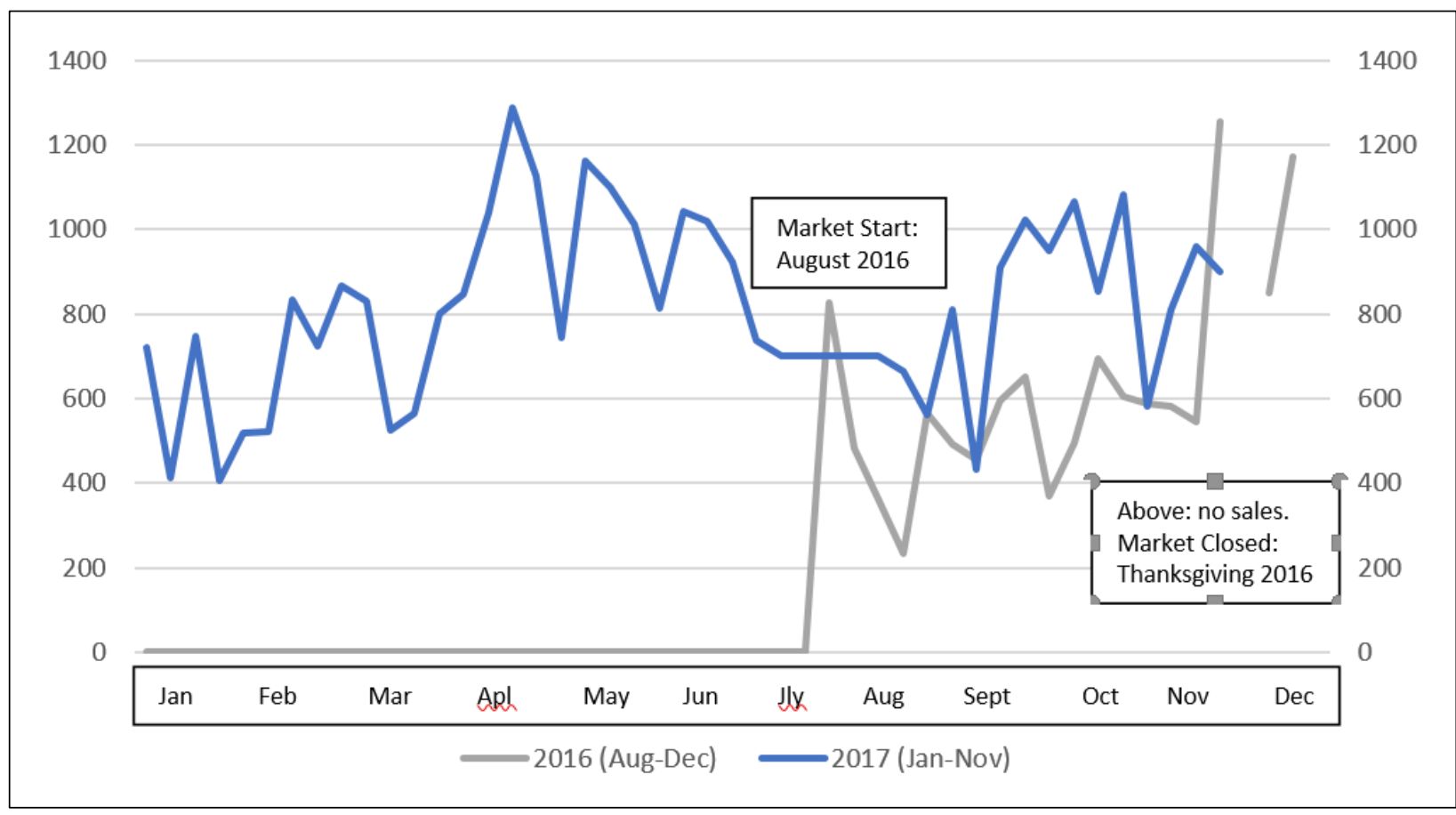


hope that it could continue (Miami County Local Food Council [MCLFC], 2018). The Miami County Local Food Council had several other projects (apart from the online market) related to promoting local food sales and consumption. It has continued and expanded these efforts around local foods. And the virtual online market continues operations today. As a private entity, we do not know sales volumes nor revenues, but hope they are growing and will continue.

\section{Reflection}

By investing time in going back, interviewing participants, and reflecting on the history of this project, we were able to learn quite a bit over the course of this three-year project. The council's online market idea, in theory, aimed to help resolve challenges that many smaller and microscale farmers face in being both farmer and salesperson. On the theoretical level, an online virtual farmers market may help, as it provides an economically viable means for smaller and microscale farmers to connect with consumers in a way that allows farmers to focus more on farming and less on the mechanics of selling their produce.

We also learned that this new, virtual platform might not fit into existing local public health categories pursuant to the aggregation and storage of produce, along with other products, from multiple growers. Our market manager indicated that locallevel public health officials helped our new venture ensure compliance, and we received approval as a "retail food establishment" under Ohio food safety laws. And though we implemented good handling practices (GHP), food selling and safety laws and their enforcement may vary dramatically across individual states and the nation. Thus, any attempt to replicate this model elsewhere should begin with a conversation with local public health officials early in the development process. This will aid in understanding how this model will interact with the letter of the law and enforcement of food safety regulations in a particular location.

Lastly, we speculated that if we expanded the concept, markets using it could see growth in sales to individual and family-scale consumers as well as small-scale commercial consumers (e.g., restaurants), because the market's infrastructure and administrative capacity would be increased. Further, markets using this model could include the products of micro- and cottage-scale value-added producers, again increasing capacity by using technology.

The model we used could have value in other communities. Members of the Miami County Local Food Council suggested that while the model has been only moderately successful in the Miami County market, they believed that the region's small potential market was a significant negative factor limiting the model's success. They believed that the use of a similar model in a community with a much larger market share has a greater likelihood of being successful. But food system professionals know that larger communities often have more options for localized produce sales, both online and with varying pick-up and delivery options (e.g., more farmers markets, CSAs, and grocery stores selling locally grown products), and so the online service may require more marketing dollars or start-up investment to reach that larger market, establish a visible footprint, and find success.

\section{Potential for Adoption or Adaptation}

Other groups seeking to adapt this model for use in their community should consider several process improvements over our approach. First, our experience showed us that the role of the market manager is vital to the overall function of an online market. This person must understand and follow local food safety regulations; understand the local agricultural industry and economy; possess basic accounting and project management knowledge; understand the management of feeding program redemption (e.g., SNAP and WIC); and know social media marketing techniques. Our project depended on these. We also noted that reliable Internet service is important at both the market manager's home and the pick-up location, to allow for greater responsiveness to customers given the 24-hour reality of online retail (the latter of which was not present in this case).

Along with structural support, a successful virtual market project needs a physical location that can provide adequate space and infrastructure for three main functions: the receipt and pickup of 
food; the storage of food in refrigerators; and office space for the market manager to complete administrative tasks. In this case study, the Troy market used a multipurpose room in a local church building. However, it did not have adequate office space, which became a challenge for our operations.

One additional consideration for the development of an online market may center on issues of the digital divide (e.g., access and proficiency with the Internet, as well as the ability to make online financial transactions). During our test, we accepted cash or check payments at pickup. Although we wanted to accept online payments at the time of ordering, we did not possess the expertise to get that set up in conjunction with our website host, who did not, at the time, offer this service. With increased options today (e.g., PayPal, Venmo, etc.), we believe this is necessary for customer service, and likely an expectation.

As noted above, access to and expertise with the Internet and social media marketing are critical to effective outreach. Providing a digital access point (e.g., a dedicated tablet or computer) for customers to complete orders at the market's distribution point can help breach the digital divide. In addition, the deliberate selection of the location of a market's physical distribution point at a visible and accessible location may assist with outreach and access as well.

\section{Recommendations and Conclusions}

In summary, developing an order and delivery system by way of an online farmers market may increase the number of customers and expand the volume of sales for local foods by offering an alternate mechanism for purchase and pick-up. While there is a cost to starting a virtual market, ours had a relatively low start-up investment, consisting mostly of the manager's salary and refrigeration equipment to satisfy food safety requirements.

Based on the convenience factors we have outlined (saving time for the consumer and limiting the farmer's loss by harvesting only what has been ordered), we believe launching a new online market can be an attractive option for both farmers and consumers. We also believe it can capture a potentially untapped share of the local food dollar from those customers who do not have time or who do not wish to go to a farmers market physically, but who still want to purchase locally grown products and support the local economy. The Troy, Ohio, online market experiment continues today, nearly four years later. However, at the time the market became a private business, sales had remained consistently below what we hoped for, and below the level to create a desirable part-time salary for a market manager. Again, this points us to think there is greater potential in a more populated, urban area where increased sales volume could generate the desired cash flow for operations. As we found extremely limited writings or research on this model, we strongly encourage further research, case studies, and exploration of the concept.

\section{References}

Anesbury, Z., Nenycz-Thiel, M., Dawes, J., \& Kennedy, R. (2016). How do shoppers behave online? An observational study of online grocery shopping. Journal of Consumer Behaviour, 15(3), 261-270. https://doi.org/10.1002/cb.1566

Brekken, C. A., Parks, M., \& Lundgren, M. (2017). Oregon producer and consumer engagement in regional food networks: Motivations and future opportunities. Journal of Agriculture, Food Systems, and Community Development, 7(4), 79-103. https://doi.org/10.5304/jafscd.2017.074.008

Cuy Castellanos, D., Jones, J. C., Christaldi, J., \& Liutkus, K. A. (2017). Perspectives on the development of a local food system: the case of Dayton, Ohio. Agroecology and Sustainable Food Systems, 41(2), 186-203. https://doi.org/10.1080/21683565.2016.1263893

Freedman, D. A., Vaudrin, N., Schneider, C., Trapl, E., Ohri-Vachaspati, P., Taggart, M., \& Flocke, S. (2016). Systematic review of factors influencing farmers' market use overall and among low-income populations. Journal of the Academy of Nutrition and Dietetics, 116(7), 1136-1155. https://doi.org/10.1016/j.jand.2016.02.010

Grigsby, C., \& Bruch Leffew, M. (2016). E-commerce for direct farm marketing: An overview of Locallygrown.net and case studies of online markets in Tennessee. University of Tennessee Extension. Retrieved from https://extension.tennessee.edu/publications/Documents/PB1857.pdf 
Jones, J. (2018). Urban food entrepreneurship, governance, and, economic development in the post-industrial cities of Newark, New Jersey, and Dayton, Ohio. Doctoral dissertation, New Jersey Institute of Technology, Newark, New Jersey.

Locally Grown. (2018). Our markets. Retrieved December 7, 2018, from http://locallygrown.net/markets/list

Long, J., Sounny-Slitine, M. A., Castles, K., Curran, J., Glaser, H., Hoyer, E., . . Parafina, B. (2013). Toward an informative and applied methodology for price comparison studies of farmers' markets and competing retailers at the local Scale. Journal of Agriculture, Food Systems, and Community Development, 3(3), 95-119. https://doi.org/10.5304/jafscd.2013.033.010

Low, S. A., Adalja, A., Beaulieu, E., Key, N., Martinez, S., Melton, A., . . Jablonski, B. B. R. (2015). Trends in US local and regional food systems: A report to Congress. Washington, D.C.: USDA Economic Research Service. Retrieved from https://www.ers.usda.gov/publications/pub-details/?pubid $=42807$

Lutz, J., Smetschka, B., \& Grima, N. (2017). Farmer cooperation as a means for creating local food systems-Potentials and challenges. Sustainability, 9(6), 925. https://doi.org/10.3390/su9060925

Miami County Local Food Council (MCLFC). (2018). Meeting notes from the Miami County Local Food Council. January 30, 2018. (Available from: OSU Extension, Miami County, 201 West Main Street, Troy, OH 45373)

Morganosky, M., \& Cude, B. (2000). Consumer response to online grocery shopping. International Journal of Retail \& Distribution Management, 28(1), 17-26. https://doi.org/10.1108/09590550010306737

O'Hara, J. K., \& Benson, M. C. (2019). Where have all the direct-marketing farms gone? Patterns revealed from the 2017 Census of Agriculture. Journal of Agriculture, Food Systems, and Community Development, 9(1), 31-37. https://doi.org/10.5304/jafscd.2019.091.046

Raison, B. (Ed.). (2013). Meeting notes from the Miami County Agricultural Economic Development Workshop, June 28, 2013. Available on request from OSU Extension, Miami County, 201 West Main Street, Troy, OH 45373 USA.

Raison, B. (Ed.). (2015). Meeting notes from the Miami County Local Food Council. February 10, 2015. Available on request from OSU Extension, Miami County, 201 West Main Street, Troy, OH 45373 USA.

Skizim, M., Sothern, M., Blaha, O., Tseng, T. S., Griffiths, L., Joseph, J., \& Nuss, H. (2017). Social marketing for a farmer's market in an underserved community: A needs assessment. Journal of Public Health Research, 6(3), $164-168$. https://doi.org/10.4081/jphr.2017.815

Tropp, D. (2019). From anecdote to formal evaluation: Reflections from more than two decades on the local food research trail at USDA. Journal of Agriculture, Food Systems, and Community Development, 9(1), 13-30. https://doi.org/10.5304/jafscd.2019.091.044

U.S. Census Bureau. (2010). QuickFacts: Ohio. Retrieved from https://www.census.gov/quickfacts/OH

White, M. (2011, October 2). Virtual farmers markets - The future. Mother Earth News. Retrieved from https://www.motherearthnews.com/homesteading-and-livestock/virtual-farmers-markets-the-future

World Food Programme. (2018). Virtual Farmers' Market: A digital solution connecting farmers to markets [Factsheet]. Retrieved from https://www.wfp.org/publications/2017-virtual-farmers $\% \mathrm{E} 2 \% 80 \% 99$-market-digital-solution-connectingfarmers-markets

Wortham, J. (2013, November 13). Good Eggs, a virtual farmer's market, delivers real food. The New York Times. Retrieved from http://www.nytimes.com/2013/11/14/technology/personaltech/goodeggs-a-virtual-farmersmarket-delivers-real-food.html

Yeo, V. C. S., Goh, S.-K., \& Rezaei, S. (2017). Consumer experiences, attitude and behavioral intention toward online food delivery (OFD) services. Journal of Retailing and Consumer Services, 35, 150-162. https://doi.org/10.1016/j.jretconser.2016.12.013 


\section{Appendix}

Table A. Weekly Sales Data (all in US\$)

\begin{tabular}{|c|c|c|c|}
\hline Week \# (2016) & Total \$ sales & Week \# (2017) & Total \$ sales \\
\hline (August 2-8) 1 & $\$ 827.57$ & (January 3-8) 20 & $\$ 721.22$ \\
\hline 2 & 481.06 & 21 & 412.67 \\
\hline 3 & 363.80 & 22 & 748.67 \\
\hline 4 & 234.72 & 23 & 407.09 \\
\hline 5 & 566.09 & 24 & 517.5 \\
\hline 6 & 491.95 & 25 & 523.11 \\
\hline 7 & 456.22 & 26 & 834.38 \\
\hline 8 & 593.79 & 27 & 724.32 \\
\hline 9 & 649.93 & 28 & 864.79 \\
\hline 10 & 368.02 & 29 & 829.78 \\
\hline 11 & 496.64 & 30 & 525.29 \\
\hline 12 & 694.10 & 31 & 565.15 \\
\hline 13 & 605.74 & 32 & 801.75 \\
\hline 14 & 587.84 & 33 & 848.21 \\
\hline 15 & 581.40 & 34 & $1,039.71$ \\
\hline 16 & 546.14 & 35 & $1,286.28$ \\
\hline 17 & $1,253.17$ & 36 & $1,126.39$ \\
\hline (Closed Thanksgiving week) & 0 & 37 & 743.17 \\
\hline (Dec. pre-holidays) 18 & 849.22 & 38 & $1,160.37$ \\
\hline (Dec. pre-holidays) 19 & $1,172.91$ & 39 & $1,098.34$ \\
\hline (Closed through 12/31) & 0 & 40 & $1,013.37$ \\
\hline \multirow[t]{20}{*}{ TOTAL for 2016} & $\$ 11,820.31$ & 41 & 812.14 \\
\hline & & 42 & 1043.54 \\
\hline & & 43 & $1,017.73$ \\
\hline & & 44 & 923.19 \\
\hline & & 45 & 735.80 \\
\hline & & 46 & 700.00 \\
\hline & & 47 & 700.00 \\
\hline & & 48 & 700.00 \\
\hline & & 49 & 700.00 \\
\hline & & 50 & 700.00 \\
\hline & & 51 & 663.63 \\
\hline & & 52 & 561.86 \\
\hline & & 53 & 809.07 \\
\hline & & 54 & 433.27 \\
\hline & & 55 & 911.05 \\
\hline & & 56 & 1022.12 \\
\hline & & 57 & 950.51 \\
\hline & & 58 & 1066.07 \\
\hline & & 59 & 852.98 \\
\hline & & 60 & 1081.93 \\
\hline
\end{tabular}


Journal of Agriculture, Food Systems, and Community Development ISSN: 2152-0801 online https://www.foodsystemsjournal.org

\begin{tabular}{lrc}
\hline & & \\
& 61 & 580.91 \\
\cline { 2 - 3 } & 62 & 811.2 \\
\cline { 2 - 3 } & 63 & 957.84 \\
\cline { 2 - 3 } & 64 & 900.10 \\
\cline { 2 - 3 } & TOTAL sales (January- \\
November 2017) & $\mathbf{\$ 3 6 , 4 2 6 . 5 0}$ \\
\hline \multicolumn{2}{c}{ Grand Total for 64 weeks: \$48,246.81 }
\end{tabular}

